\title{
PREVALENCE OF HEPATITIS B INFECTION IN A TERTIARY CARE HOSPITAL IN BIHAR
}

\author{
Lal Arjun'1, Kumar Ajay², Nag Sanjay33, Rajpal Kamlesh4, Mahto Sushil Prasad ${ }^{5}$ \\ 1 Assistant Professor, Department of Microbiology, Anugrah Narayan Magadh Medical College (ANMMC), Gaya. \\ ${ }^{2}$ Senior Resident, Department of Microbiology, Indira Gandhi Institute of Medical Sciences (IGIMS), Patna. \\ ${ }^{3}$ Assistant Professor, Department of Microbiology, Anugrah Narayan Magadh Medical College (ANMMC), Gaya. \\ ${ }^{4}$ Assistant Professor, Department of Microbiology, Anugrah Narayan Magadh Medical College (ANMMC), Gaya. \\ 5Professor, Department of Microbiology, Anugrah Narayan Magadh Medical College (ANMMC), Gaya.
}

\section{BACKGROUND}

ABSTRACT

Hepatitis B virus (HBV) is one of the major global public health problems. HBV infection is the $10^{\text {th }}$ leading cause of death and HBVrelated Hepatocellular carcinoma (HCC) is the $5^{\text {th }}$ most frequent cancer worldwide. The present study was conducted to determine the seroprevalence of HBV in high-risk groups.

\section{MATERIALS AND METHODS}

Serum samples were collected from clinically diagnosed Hepatitis patients and screened for anti-HBV antibodies using Immunochromatographic card test and confirmed by ELISA.

\section{RESULTS}

Among 400 serum samples collected, 136 (34\%) were reactive for antigen to HBV. All 136 sero-reactive patients belonged to a high-risk group, as they were undergoing blood transfusion.

\section{CONCLUSION}

This study was an effort to highlight the main risk factors that led to Hepatitis B Virus infection. The role of universal precaution cannot be overemphasised. However, this study suggests that strategy can be instituted to identify the high-risk population with past history of jaundice or contact with jaundiced person (household contact).

\section{KEYWORDS}

Hepatitis B, ELISA, Prevalence.

HOW TO CITE THIS ARTICLE: Arjun L, Ajay K, Sanjay N, et al. Prevalence of hepatitis B infection in a tertiary care hospital in Bihar. J. Evolution Med. Dent. Sci. 2017;6(89):6189-6191, DOI: 10.14260/jemds/2017/1345

\section{BACKGROUND}

Communicable diseases remain a significant public health problem despite the progress in diagnosis, treatment, prevention and the widespread use of antibiotics and vaccination. Nowadays, sexually transmitted diseases (STDs), food-borne diseases, emergence of antimicrobial-resistant bacteria, vector-borne diseases and vaccine preventable diseases are still considered of high concern both at National and International levels. ${ }^{1}$

The World Health Organisation (WHO) considers hepatitis $B$ virus (HBV) to be second to tobacco among the carcinogens. ${ }^{2}$ Hepatitis B infection is caused by Hepatitis B virus, which is a DNA virus belonging to the family Hepadnaviridae, which can cause acute or chronic infection. ${ }^{3}$ Hepatitis $\mathrm{B}$ virus (HBV) is one of the major global public health problems. According to World Health Organisation estimation, about 30 percent of the world population has serological evidence of current or past infection with Hepatitis $B$ virus. Of these, an estimated 350 million are chronically infected with Hepatitis B and approximately 1 million persons

'Financial or Other Competing Interest': None.

Submission 20-09-2017, Peer Review 01-11-2017,

Acceptance 07-11-2017, Published 13-11-2017.

Corresponding Author:

Dr. Kumar Ajay,

Senior Resident, Department of Microbiology,

Indira Gandhi Institute of Medical Sciences,

(IGIMS), Patna-14.

E-mail:dr.ajay876@gmail.com

DOI: $10.14260 /$ jemds $/ 2017 / 1345$

\section{(c) $($ ) $\$$}

die annually from Hepatitis B virus-related chronic liver diseases including severe complications such as liver cirrhosis and hepatocellular carcinoma. HBV infection is the tenthleading cause of death and HBV-related hepatocellular carcinoma (HCC) is the fifth most frequent cancer worldwide. ${ }^{4,5}$

Viral hepatitis is caused by 5 different viruses, Hepatitis A, B, C, D and E. Hepatitis A and E are transmitted by faeco-oral route, while hepatitis $B, C$ and $D$ are transmitted by blood or sexual route. Chronic hepatitis occurs with Hepatitis B and C virus. Structurally, it consists of partially double-stranded DNA and nucleocapsid core antigen ( $\mathrm{HBcAg}$ ) that encloses the viral DNA. The viral envelope encoded by the $S$ gene that represents hepatitis B surface antigen (HBsAg). Hepatitis B envelop antigen ( $\mathrm{HBeAg}$ ) is a circulating peptide, which is derived from the core gene and then it is modified and exported from liver cells, serving as a marker of active viral replication as $\mathrm{HBeAg}$, which is substantially related to its infectivity. ${ }^{6}$ HBV strains isolated worldwide have been classified into six genomic groups deduced from genome comparisons and designated genotypes A to F.7,8 Chronic, persistent HBV infection develops at the end-stage of liver disease, such as liver cirrhosis and hepatocellular carcinoma. ${ }^{9}$ Although, safe and effective HBV vaccine is available, but new cases of HBV infection are still reported throughout the world. ${ }^{10}$ Recently, occult HBV infections were also reported in which the serological HBsAg was negative in the patient sera, but the HBV DNA could be detected by PCR. The appearance of HBsAg is the first evidence of infection appearing before 
biochemical evidence of liver disease and persists throughout the clinical illness. Persistence of HBsAg after the acute illness, may be associated with clinical and laboratory evidence of chronic hepatitis for variable period of time.

\section{MATERIALS AND METHODS}

This retrospective descriptive study was conducted in Department of Microbiology, Anugrah Narayan Magadh Medical College and Hospital, Gaya, from a period of August 2015 to July 2016. The serum sample were screened for antigen detection to HBV using SD BIOLINE HBsAg kit. The positive serum samples were confirmed by ELISA using HBV Micro-ELISA. The data was recorded from Blood Banks where patients come for blood donation, from the log book and computer records from over one year duration from August 2015 to July 2016. Regarding patients testing positive, records showed that infection was received mostly through sexual contact and most of the people had not received any immunisation.

\section{Statistical Test}

Statistical analyses were done using SPSS 7. Results were calculated in proportion and percentage.

\section{RESULTS}

Serum samples from 136 patients were reactive for antigen to HBV out of the total 400 patients. The results were confirmed by ELISA. The prevalence rate for HBV infection was $34 \%$; 340 patients out of the 400 patients were undergoing blood transfusion and all the 136 patients who were reactive for HBV antigen belonged to this group. The prevalence rate among haemodialysis patients was $46 \%$. All these 136 patients were non-reactive for co-infection with HIV and Hepatitis B.

\section{DISCUSSION}

Viral Hepatitis is an infection which is transmitted by the parenteral, perinatal or sexual route. One of the aetiological causes for infective Hepatitis is Hepatitis B Virus (HBV). The prevalence in the present study was $34 \%$. All the patients found positive for Hepatitis infection were donor patients. The prevalence of the infection in blood donor patients was $46 \%$. Patients on recipient are at an increased risk for acquiring hepatitis B infection as a result of blood transfusion.(11) These patients are also anaemic and weak, often requiring multiple blood transfusions making them susceptible to acquire the infection. A significant relation was found between blood or blood product transfusion and Hepatitis B infection; 10 (20\%) of the cases received blood (or any of its products) compared to $4(4 \%)$ of the controls. Thus, Blood transfusion is a significant risk factor for Hepatitis B infection by univariate analysis. This might be due to improper screening of blood before transfusion.

A study conducted in Nigeria among pregnant women showed that the history of blood transfusion is a significant risk factor. ${ }^{12}$ As well a cross-sectional study done among health care workers in Uganda showed same results. ${ }^{13}$ This finding support the conclusion by Al-Hindi and Colleagues. ${ }^{14}$ that the routine tests screening of blood units and its products to detect Hepatitis B infection by HBsAg test alone is not enough and there is a need to consider introducing Anti-HBc test and HBV DNA in order to discover the occult HBV, to minimise the risk of HBV transmission by blood and its products.

In Brazil, it was shown that blood transfusion is among the predictors of the HBV exposure. In two different studies conducted in Italy, blood transfusion and surgical intervention were among the independent risk factors. ${ }^{15,16}$

The usual immunisation schedule recommended for prevention of Hepatitis B consists of three doses of the vaccine: the first two doses one month apart, while the third dose is given after 5 months of the second dose. Infants born to infected mothers may be given Hepatitis B immunoglobulin (HBIG) as an additional protection.

The duration of immunity after Hepatitis B vaccination was studied by measuring the decline of Anti-HBs level finding that there is rapid decline in the first year after the third dose of vaccination among adults, then gradual decrease continued after 5 years. The concentration becomes $<10$ $\mathrm{mIU} / \mathrm{mL}$ in $7 \%-50 \%$ of the vaccines.

No specific management for acute hepatitis, but just supportive and symptomatic treatment is indicated. In terms of chronic infection, many antiviral drugs were studied and proved to reduce the HBV replication and normalise the liver enzymes including alpha- $2 \mathrm{~b}$ interferon and nucleotide analogues such as lamivudine. ${ }^{17}$

\section{CONCLUSION}

The present study shows that the known risk factors are also significant in the transmission of Hepatitis B in Bihar. The role of universal precaution cannot be overemphasised. It revealed that several high-risk behaviours and practices for the transmission of this infection are significantly more prevalent among the cases compared to the controls. Our data indicates that a history of blood transfusion, history of hospitalisation, history of surgery, past treatment of STD and family history of hepatitis B are important risk factors for HBV infection in our area. The adoption of infection prevention standards as strategy is the key of Hepatitis B prevention and other bloodborne pathogens, while health education for the personal hygiene will protect the public emphasising on the vaccination of the risky behaviour groups as a first protective line. However, this study suggests that strategy can be instituted to identify the high-risk population with past history of jaundice or contact with jaundiced person (household contact). This study can help in monitoring the population to detect clearing of HBsAg or followup for further intervention to prevent chronic HBsAg carrier state and its complications. Hepatitis B infection is still a public health problem despite the availability of the Hepatitis B vaccine, which is largely attributed to its asymptomatic course and carrier patients. Identification of Hepatitis B risk factors and development of prevention strategies based on epidemiological studies can form the basis for developing a comprehensive prevention strategy to prevent blood-borne pathogen transmission, such as HBV and HIV in Bihar. This study can enable us to identify the high-risk segment of the population and offers a window of opportunity for intervention to minimise the impact of the disease in the community. 


\section{REFERENCES}

[1] Halliday L, Petersen M. Communicable diseases in the ACT. Epidemiology Unit, ACT Dept of Health and Community Care: Health Series No 20, ACT Government Printer 1993-97.

[2] www.who.int/entity/csr/disease/hepatitis/HepatitisBw hocdscsrlyo2002_2.pdf.

[3] Kasper D, Braunwald E, Fauci A. Harrison's Principles of internal medicine. $16^{\text {th }}$ edn. The McGraw-Hill 2005.

[4] WHO. Hepatitis B. Fact sheets. Hepatitis B factsheet $\mathrm{N}^{\circ} 204$.

2013. http://www.who.int/mediacentre/factsheets/fs204/en

[5] Lavanchy D. Hepatitis B virus epidemiology, disease burden, treatment and current and emerging prevention and control measures. Journal Viral Hepatitis 2004;11(2):97-107.

[6] Haslett C, Chilvers ER, Hunter JAA, et al. Davidson's Principles and practice of medicine. $18^{\text {th }}$ edn. Churchill Livingstone 1999.

[7] Mahoney FJ. Update on diagnosis, management, and prevention of Hepatitis B virus infection. Clinical Microbiology Reviews 1999;12(2):351- 66.

[8] Magnius LO, Norder H. Subtypes, genotypes and molecular epidemiology of the hepatitis B virus as reflected by sequence variability of the S-gene. Intervirology 1995;38(1-2):24-34.

[9] Okamoto H, Tsuda F, Sakugawa H, et al. Typing hepatitis $\mathrm{B}$ virus by homology in nucleotide sequence: comparison of surface antigen subtypes. J Gen Virol 1988;69(Pt 10): 2575-83.
[10] Bruix J, Llovet JM. Hepatitis B virus and hepatocellular carcinoma. J Hepatol 2003;39(Suppl 1):S59-S63.

[11] Adachi S, Shibuya A, Miura Y, et al. Impact of occult hepatitis B virus infection and prior hepatitis B virus infection on development of hepatocellular carcinoma in patients with liver cirrhosis due to hepatitis $\mathrm{C}$ virus. Scand J Gastroenterol 2008;43(7):849-56.

[12] Omalu ICJ, Jibrin A, Olayemi IK, et al. Seroprevalence of malaria and Hepatitis B (HBsAg) with associated risk factors among pregnant women attending antenatal clinic in general hospital Minna, North-Central Nigeria. Annual Review \& Research in Biology 2012;2(4):83-8.

[13] Shiha AM, AbuTaha A, Dumaidi K. Prevalence of Hepatitis $B$ virus DNA among blood donors in Nablus-West Bank. An-Najah National University, faculty of graduate studies. Department of Public Health, 80. 2011. http://scholar.najah.edu sites thesis Amira Shiha

[14] Stroffolini T, Mele A, Tosti ME, et al. The impact of the Hepatitis B mass immunisation campaign on the incidence and risk factors of acute Hepatitis B in Italy. J Hepatol 2000;33(6):980-5.

[15] Alter MJ. Epidemiology of Hepatitis B in Europe and worldwide. J Heptal 2003;39(Suppl 1):S64-9.

[16] WHO. Advances in viral Hepatitis. Report of the WHO Expert Committee on viral Hepatitis. Geneva. Techn Rep Ser. No. 602. 1977.

[17] Pan CQ, Zhang JX. Natural history and clinical consequences of HBV infection. Int J Med Sci 2005:2(1):36-40. 